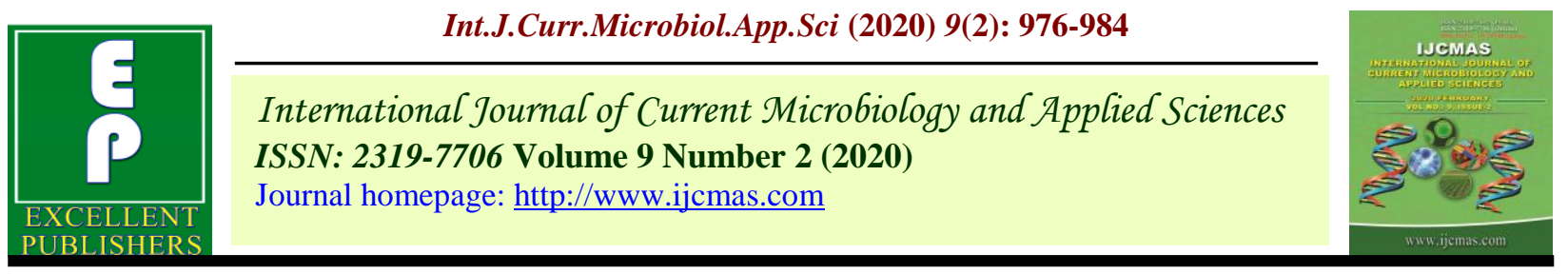

Original Research Article

https://doi.org/10.20546/ijcmas.2020.902.114

\title{
Interaction Effect of Different Sowing Dates and Irrigation Schedule on Yield Attributes of Wheat Cultivars under Rajasthan Conditions
}

\author{
Arjun Lal Prajapat ${ }^{\text {* }}$, Rani Saxena ${ }^{1}$, R. C. Sanwal ${ }^{2}$ and Manoj Kumhar ${ }^{3}$ \\ ${ }^{1}$ Division of Agronomy, Rajasthan Agricultural Research Institute, SKNAU, \\ Durgapura, Jobner 302018 \\ ${ }^{2}$ Department of Soil Science, College of Agriculture, SKRAU, Bikaner, 344006 \\ ${ }^{3}$ Department of Entomology, SKNAU, Jobner, 303329, India \\ *Corresponding author
}

\begin{tabular}{|l|}
\hline Ke y w or d s \\
$\begin{array}{l}\text { Wheat, irrigation } \\
\text { schedule, sowing } \\
\text { date and cultivar }\end{array}$ \\
\hline Article Info \\
\hline $\begin{array}{l}\text { Accepted: } \\
\text { 08 January } 2020 \\
\text { Available Online: } \\
\text { 10 February } 2020\end{array}$ \\
\hline
\end{tabular}

A B S T R A C T

A field experiment was conducted under loamy sand soil during two consecutive Rabi seasons of 2016-17 and 2017-18 at Research Farm, Rajasthan Agricultural Research Institute, Sri Karan Narendra Agriculture University, Durgapura, Jobner. The experiment comprises four irrigation scheduling treatments (Irrigation at 0.6 ETc, 0.8 ETc, 1.0 ETc and 1.2 ETc), three cultivars (Raj 4120, Raj 4079 and Raj $4238)$ and three dates of sowing $\left(15^{\text {th }}\right.$ November, $30^{\text {th }}$ November and $15^{\text {th }}$ December) assigned, respectively to main plot, sub plot and sub-sub plots were replicated three times in split plot design. The results revealed that spike length and grains per spike of wheat crop were significantly influenced by different dates of sowing, varieties and irrigation schedules. Among different varieties, sowing dates and irrigation schedules, the maximum spike length, number of spikelet per spike, grains per spike and grain yield was recorded with variety Raj 4079 sowing of wheat on $15^{\text {th }}$ Nov. and irrigation scheduling at 1.2 Etc, respectively. Sowing of wheat variety Raj 4079 on $15^{\text {th }}$ Nov along with 1.2 ETc irrigation scheduling resulted in maximum spike length $(12.77 \mathrm{~cm})$, grains per spike $(50.64)$, spikelets per spikes (19.04) and grain yield (5968 $\left.\mathrm{kg} \mathrm{ha}^{-1}\right)$.

\section{Introduction}

Wheat is the world's largest grown cereal crop, belonging to family 'Graminae' and genus Triticum. It is the $3^{\text {rd }}$ most produced cereal after maize and rice in world. Currently it is grown on an area of about 224.82 million hectares and production of about 732.98 million tonnes with productivity of 3.26 tonnes per hectare (Anonymous, 2015a). India ranks second in terms of area, production \& productivity next to China. Wheat is an important food crop of the world as it provides food to $36 \%$ of the global population. Wheat contains about $10-14 \%$ protein, $1-2 \%$ total fat, $0.3-0.5 \%$ 
carbohydrates (DWR, annual report 2015). Wheat is an important Rabi crop, which is grown in between September \& December \& harvested between February \& May.

It is grown in diverse agro-climatic conditions from $11{ }^{0} \mathrm{~N}-35{ }^{0} \mathrm{~N}$ latitude and $72{ }^{0} \mathrm{E}-92{ }^{0} \mathrm{E}$ longitudes. It is mainly cultivated in Indo Gangetic plains which accounts for roughly 20 million hectares covering states like Punjab, Uttar Pradesh, Madhya Pradesh, Haryana, Bihar and West Bengal.

India has the largest area under wheat cultivation (30.4 million hectares), but ranks second in production (99.70 million tonnes) after China with the average productivity of $3279 \mathrm{~kg} \mathrm{ha}^{-1}$ (ICAR-IIWBR, 2018). India is blessed with both the rich land and extremely suitable weather climate for crops production.

Therefore, the rate of wheat production is second highest in the world. There are still many factors, which are responsible for low average yield of wheat in this country. One of such environmental factors is untimely planting which affects the yield of wheat crop considerably (Saini et al., 1988). Another important aspect is lack of improved cultivars which are having short maturity and suitable under late sown condition due to relatively shorter growing period available to the crop.

Moreover, varieties also vary both in yield and nutrient uptake under late sown condition (Singh et al., 1997). Earlier it was reported that wheat crop, apart from being governed by genetic characters depend largely on a number of environmental factors, which vary under different sowing dates (Saini et al., 1988).

The sowing of wheat is delayed either to fit it in multiple or relay crop sequence, where wheat is sown after very short duration winter (Rabi) crop or after long duration rice crop or
Sugarcane ratoon. Thus, the yield of wheat decreases with delayed sowing though the magnitude of reduction varies with the varieties. The sowing time is the most important factor determining the yield of wheat.

There are many factors responsible for low yield of wheat but poor irrigation and use of varieties with low yield potential are most important (Mehta and Mathur, 1979). Earlier researchers showed that irrigation consistently increased wheat yields in Pakistan (Hussain et al., 2015). Moreover, Wajid et al., (2002) reported that wheat crop produced highest grain yield by applying irrigation at all definable growth stages.

Because irrigation is an expensive input, so farmer, agronomist and economist need to know the response of yield to irrigation. Keeping in view of the aforesaid facts, the present study was undertaken to evaluate the performance and adaptability of newly developed varieties of wheat to a wider range of sowing dates in irrigated conditions.

\section{Materials and Methods}

The field experiment was conducted during Rabi season 2016 and 2017 at Research farm, Rajasthan Agricultural Research Institute, Sri Karan Narendra Agriculture University, Durgapura, Jobner, Rajasthan $\left(75^{\circ} 47^{\prime}\right.$ East longitudes, $26^{\circ} 51^{\prime}$ ' North latitude and at altitude of $390 \mathrm{~m}$ above mean sea level).

The soil of experimental field was loamy sand in texture, slightly alkaline in reaction containing $0.25 \%$ organic $\mathrm{C}$, with $p \mathrm{H} 8.2$, EC $0.15 \mathrm{ds} \mathrm{m}^{-1}$, available nitrogen $136.5 \mathrm{~kg} \mathrm{ha}^{-1}$, phosphorous $33.30 \mathrm{~kg} \mathrm{ha}^{-1}$ and potassium $195.45 \mathrm{~kg} \mathrm{ha}^{-1}$. The meteorological data was recorded daily from sowing to harvest from meteorological observatory situated near the experimental farm. 
The experimental site characterized by aridity of the atmosphere and extremity of temperature both in summer $\left(45.5^{\circ} \mathrm{C}\right)$ and winter $\left(4^{\circ} \mathrm{C}\right)$. Under semi-arid climatic conditions, the area receives $500-700 \mathrm{~mm}$ per annum rainfall which is mostly occurring during July to September. Rainfall received during the wheat growing season (Nov. to April) was $22.9 \mathrm{~mm}$.

The mean monthly maximum and minimum temperatures during the wheat growing season (Nov. to April) varied from 21.55 to 38.32 and 6.05 to $23.25^{\circ} \mathrm{C}$, respectively. The cumulative bright sunshine hours during the growing season varied between 6.70 to 10.05 hrs. The experiment was laid out in Split plot design with three replications. Thirty six treatment combinations were investigated.

Treatments comprises four irrigation levels: $\mathrm{I}_{1}$ $(0.6 \mathrm{ETc}), \mathrm{I}_{2}(0.8 \mathrm{ETc}), \mathrm{I}_{3}(1.0 \mathrm{ETc})$ and $\mathrm{I}_{4}$ (1.2 ETc), three cultivars: $C_{1}$ (Raj-4120), $C_{2}$ (Raj-4079) and $\mathrm{C}_{3}$ (Raj-4238) and three dates of sowing: $D_{1}\left(15^{\text {th }}\right.$ Nov. $), D_{2}\left(30^{\text {th }}\right.$ Nov. $)$ and $\mathrm{D}_{3}\left(15^{\text {th }}\right.$ Dec. $)$.

In the recommended irrigation treatments applied at different irrigation intervals according to $\mathrm{ET}_{\mathrm{C}}$ level with the help of water meter. Standard crop production practice and methods were followed for weeding, fertilizer application and crop protection management to grow the crop.

Observations of different yield attributes including spike length was counted separately which were obtained randomly from five tagged plants and their averages were recorded.

For determining number of spikelet per spike and number of grains per spike, five spikes were selected at random from each plot and the number of grains in each spike was counted and their mean was recorded. The data were analyzed statistically using standard tools.

\section{Results and Discussion}

\section{Spike length (cm)}

Results revealed (Table: 1.) that spike length of wheat was significantly influenced by interaction of cultivar and sowing date. Results showed that the highest spike length was obtained from $\mathrm{D}_{1} \mathrm{~V}_{2}$ (12.01, 12.37 and $12.19 \mathrm{~cm}$ ) which were statistically similar with $\mathrm{D}_{1} \mathrm{~V}_{3}(11.83,12.15$ and $11.99 \mathrm{~cm})$.

On the other hand the lowest spike length was observed at $\mathrm{D}_{3} \mathrm{~V}_{1}(5.99,6.07$ and $6.03 \mathrm{~cm})$ in both the year of study and pooled analysis, respectively. Interaction effect of improved wheat cultivar and irrigation showed significant differences on spike length.

Results showed (Table: 1.) that the highest spike length was obtained from $\mathrm{I}_{4} \mathrm{~V}_{2}$ (12.66, 12.87 and $12.77 \mathrm{~cm}$ ) which was statistically at par with $\mathrm{I}_{4} \mathrm{~V}_{3}(12.47,12.65$ and $12.56 \mathrm{~cm})$, $\mathrm{I}_{3} \mathrm{~V}_{2}(12.25,12.68$ and $12.47 \mathrm{~cm})$ and $\mathrm{I}_{3} \mathrm{~V}_{3}$ $(12.07,12.47$ and $12.27 \mathrm{~cm})$ in both the year of study and pooled analysis, respectively.

On the other hand the lowest spike length was observed at $\mathrm{I}_{1} \mathrm{~V}_{1}(4.91,5.03$ and $4.97 \mathrm{~cm})$. Further data on Interaction effect of different levels of irrigation and sowing date showed significant differences on spike length of these three types of modern wheat Cultivar.

Results showed that the maximum spike length was recorded in $\mathrm{I}_{4} \mathrm{D}_{1}(12.96,13.14$ and $13.05 \mathrm{~cm}$ ) which was recorded at par with $\mathrm{I}_{3} \mathrm{D}_{1}(12.53,12.95$ and $12.74 \mathrm{~cm})$ and the lowest was at $\mathrm{I}_{1} \mathrm{D}_{3}(5.05,5.11$ and $5.08 \mathrm{~cm})$ in both the year of study and pooled analysis, respectively. These results are in closed conformity of (Suhail et al., 2002; Shah et al., 2006). 
Table.1 Interaction effects of irrigation scheduling, cultivars and varying sowing dates on spike length of wheat

\begin{tabular}{|c|c|c|c|c|c|c|c|c|c|c|c|c|c|}
\hline \multicolumn{14}{|l|}{ I Year } \\
\hline V x D & $\mathrm{D}_{1}$ & $\mathbf{D}_{2}$ & $\mathbf{D}_{3}$ & I X V & $\mathbf{I}_{1}$ & $\mathbf{I}_{2}$ & $\mathbf{I}_{3}$ & $\mathbf{I}_{4}$ & I X D & $\mathbf{I}_{1}$ & $\mathbf{I}_{2}$ & $\mathbf{I}_{3}$ & $\mathbf{I}_{4}$ \\
\hline$V_{1}$ & 8.46 & 7.78 & 5.99 & $V_{1}$ & 4.91 & 7.19 & 8.62 & 8.91 & $D_{1}$ & 7.13 & 10.44 & 12.53 & 12.96 \\
\hline$V_{2}$ & 12.01 & 11.05 & 8.51 & $V_{2}$ & 6.97 & 10.21 & 12.25 & 12.66 & $\mathbf{D}_{2}$ & 6.56 & 9.60 & 11.53 & 11.91 \\
\hline$V_{3}$ & 11.83 & 10.88 & 8.38 & $\mathbf{V}_{\mathbf{3}}$ & 6.87 & 10.06 & 12.07 & 12.47 & $\mathbf{D}_{3}$ & 5.05 & 7.40 & 8.88 & 9.18 \\
\hline SEm \pm & 0.16 & & & SEm \pm & 0.26 & & & & SEm \pm & 0.18 & & & \\
\hline CD & 0.44 & & & CD & 0.78 & & & & CD & 0.51 & & & \\
\hline \multicolumn{14}{|l|}{ II Year } \\
\hline V x D & $\mathbf{D}_{1}$ & $\mathbf{D}_{2}$ & $\mathbf{D}_{3}$ & I X V & $\mathbf{I}_{1}$ & $\mathbf{I}_{2}$ & $\mathbf{I}_{3}$ & $\mathbf{I}_{\mathbf{4}}$ & I X D & $\mathbf{I}_{1}$ & $\mathbf{I}_{2}$ & $\mathbf{I}_{3}$ & $\mathbf{I}_{4}$ \\
\hline$V_{1}$ & 8.68 & 8.08 & 6.07 & $V_{1}$ & 5.03 & 7.47 & 8.90 & 9.03 & $D_{1}$ & 7.31 & 10.86 & 12.95 & 13.14 \\
\hline$V_{2}$ & 12.37 & 11.51 & 8.64 & $V_{2}$ & 7.16 & 10.64 & 12.68 & 12.87 & $\mathbf{D}_{2}$ & 6.81 & 10.11 & 12.05 & 12.23 \\
\hline$V_{3}$ & 12.15 & 11.31 & 8.49 & $V_{3}$ & 7.04 & 10.46 & 12.47 & 12.65 & $\mathbf{D}_{3}$ & 5.11 & 7.59 & 9.05 & 9.19 \\
\hline SEm \pm & 0.16 & & & SEm \pm & 0.26 & & & & SEm \pm & 0.18 & & & \\
\hline CD & 0.44 & & & CD & 0.78 & & & & CD & 0.51 & & & \\
\hline \multicolumn{14}{|l|}{ Pooled } \\
\hline V x D & $\mathbf{D}_{1}$ & $\mathbf{D}_{2}$ & $\mathbf{D}_{3}$ & I X V & $\mathbf{I}_{1}$ & $\mathbf{I}_{2}$ & $\mathbf{I}_{3}$ & $\mathbf{I}_{\mathbf{4}}$ & I X D & $\mathbf{I}_{1}$ & $\mathbf{I}_{2}$ & $\mathbf{I}_{3}$ & $\mathbf{I}_{4}$ \\
\hline$V_{1}$ & 8.57 & 7.93 & 6.03 & $V_{1}$ & 4.97 & 7.33 & 8.76 & 8.97 & $D_{1}$ & 7.22 & 10.65 & 12.74 & 13.05 \\
\hline $\mathbf{V}_{2}$ & 12.19 & 11.28 & 8.58 & $V_{2}$ & 7.07 & 10.42 & 12.47 & 12.77 & $\mathbf{D}_{2}$ & 6.68 & 9.86 & 11.79 & 12.07 \\
\hline $\mathbf{V}_{3}$ & 11.99 & 11.10 & 8.44 & $V_{3}$ & 6.95 & 10.26 & 12.27 & 12.56 & $\mathbf{D}_{3}$ & 5.08 & 7.50 & 8.97 & 9.18 \\
\hline SEm \pm & 0.11 & & & SEm \pm & 0.19 & & & & SEm \pm & 0.12 & & & \\
\hline CD & 0.31 & & & CD & 0.53 & & & & CD & 0.39 & & & \\
\hline
\end{tabular}

\section{Spikelets per spike}

Spikelets spike ${ }^{-1}$ of wheat was significantly influenced by the interaction of cultivar and sowing date at all samples. Results showed (Table: 2.) that the highest spikelets spike ${ }^{-1}$ was obtained from $\mathrm{D}_{1} \mathrm{~V}_{2}(18.16,18.77$ and 18.47) which was statistically similar with $\mathrm{D}_{1} \mathrm{~V}_{3}(17.89,18.38$ and 18.14). On the other hand the lowest spikelets spike ${ }^{-1}$ was observed at $\mathrm{D}_{3} \mathrm{~V}_{1}(9.16,9.30$ and 9.23) which was followed by $\mathrm{D}_{2} \mathrm{~V}_{1}(12.12,12.38$ and 12.25 ) in both the year of study and pooled analysis, respectively. These results are in accordance with those of (Mesbah, 2009; Dixit et al., 2014).

Interaction effect of improved wheat cultivar and irrigation showed significant differences on spikelets spike ${ }^{-1}$ at all sampling dates. Results revealed (Table: 2.) that the highest spikelets spike ${ }^{-1}$ were obtained from $\mathrm{I}_{4} \mathrm{~V}_{2}$ 
$(18.87, \quad 19.21$ and 19.04) which was statistically similar with $\mathrm{I}_{4} \mathrm{~V}_{3}(18.59,18.81$ and 18.70), $\mathrm{I}_{3} \mathrm{~V}_{2}(18.31,18.85$ and 18.58) and $\mathrm{I}_{3} \mathrm{~V}_{3}(18.04,18.45$ and 18.25).

On the other hand the lowest spikelets spike ${ }^{-1}$ was observed at $I_{1} V_{1}(8.07,8.29$ and 8.18) in both the year of study and pooled analysis, respectively. Interaction effect of different levels of irrigation and sowing date showed significant differences on spikelets spike ${ }^{-1}$ of these three types of modern wheat cultivar. A critical examination of data (Table: 2.) indicated that the maximum spikelets spike ${ }^{-1}$ found in $\mathrm{I}_{4} \mathrm{D}_{1}(18.95,19.25$ and 19.10) which was observed similar at $\mathrm{I}_{3} \mathrm{D}_{1}(18.39,18.89$ and 18.64) and the lowest spikelets spike ${ }^{-1}$ was observed at $\mathrm{I}_{1} \mathrm{D}_{3}(8.35,8.57$ and 8.46) in both the year of study and pooled analysis, respectively.

Table.2 Interaction effect of irrigation scheduling, cultivars and varying sowing dates on number of spikletes per spike of wheat

\begin{tabular}{|c|c|c|c|c|c|c|c|c|c|c|c|c|c|}
\hline \multicolumn{14}{|l|}{ I Year } \\
\hline$V \times D$ & $D_{1}$ & $\mathbf{D}_{2}$ & $\mathbf{D}_{3}$ & I X V & $\mathbf{I}_{1}$ & $\mathbf{I}_{2}$ & $\mathbf{I}_{3}$ & $\mathbf{I}_{4}$ & I X D & $\mathbf{I}_{1}$ & $\mathbf{I}_{2}$ & $\mathbf{I}_{3}$ & $\mathbf{I}_{4}$ \\
\hline$V_{1}$ & 12.72 & 12.12 & 9.16 & $V_{1}$ & 8.07 & 11.22 & 12.82 & 13.21 & $\mathbf{D}_{1}$ & 11.58 & 16.10 & 18.39 & 18.95 \\
\hline $\mathbf{V}_{2}$ & 18.16 & 17.30 & 13.09 & $\mathbf{V}_{2}$ & 11.53 & 16.03 & 18.31 & 18.87 & $\mathbf{D}_{2}$ & 11.03 & 15.34 & 17.52 & 18.06 \\
\hline $\mathbf{V}_{3}$ & 17.89 & 17.05 & 12.89 & $\mathbf{V}_{3}$ & 11.36 & 15.79 & 18.04 & 18.59 & $\mathbf{D}_{3}$ & 8.35 & 11.60 & 13.25 & 13.66 \\
\hline SEm \pm & 0.21 & & & SEm \pm & 0.32 & & & & $\operatorname{SEm} \pm$ & 0.24 & & & \\
\hline CD & 0.59 & & & CD & 0.97 & & & & CD & 0.68 & & & \\
\hline \multicolumn{14}{|l|}{ II Year } \\
\hline$V \times D$ & $D_{1}$ & $\mathbf{D}_{2}$ & $\mathbf{D}_{3}$ & I X V & $\mathbf{I}_{1}$ & $\mathbf{I}_{2}$ & $\mathbf{I}_{3}$ & $\mathbf{I}_{4}$ & I X D & $\mathbf{I}_{1}$ & $\mathbf{I}_{2}$ & $\mathbf{I}_{3}$ & $\mathbf{I}_{4}$ \\
\hline$V_{1}$ & 13.01 & 12.38 & 9.30 & $V_{1}$ & 8.29 & 11.59 & 13.07 & 13.32 & $D_{1}$ & 11.98 & 16.76 & 18.89 & 19.25 \\
\hline $\mathbf{V}_{2}$ & 18.77 & 17.86 & 13.42 & $\mathbf{V}_{2}$ & 11.96 & 16.72 & 18.85 & 19.21 & $\mathbf{D}_{2}$ & 11.40 & 15.94 & 17.97 & 18.31 \\
\hline $\mathbf{V}_{3}$ & 18.38 & 17.48 & 13.14 & $\mathbf{V}_{3}$ & 11.71 & 16.37 & 18.45 & 18.81 & $\mathbf{D}_{3}$ & 8.57 & 11.98 & 13.51 & 13.76 \\
\hline SEm \pm & 0.21 & & & SEm \pm & 0.34 & & & & SEm \pm & 0.25 & & & \\
\hline CD & 0.61 & & & CD & 1.02 & & & & CD & 0.71 & & & \\
\hline \multicolumn{14}{|l|}{ Pooled } \\
\hline $\mathbf{V} \times \mathbf{D}$ & $D_{1}$ & $D_{2}$ & $\mathbf{D}_{3}$ & I X V & $\mathbf{I}_{\mathbf{1}}$ & $\mathbf{I}_{2}$ & $\mathbf{I}_{3}$ & $\mathbf{I}_{4}$ & I X D & $\mathbf{I}_{1}$ & $\mathbf{I}_{2}$ & $\mathbf{I}_{3}$ & $\mathbf{I}_{4}$ \\
\hline$V_{1}$ & 12.86 & 12.25 & 9.23 & $V_{1}$ & 8.18 & 11.41 & 12.94 & 13.26 & $D_{1}$ & 11.78 & 16.43 & 18.64 & 19.10 \\
\hline $\mathbf{V}_{2}$ & 18.47 & 17.58 & 13.25 & $V_{2}$ & 11.74 & 16.37 & 18.58 & 19.04 & $\mathbf{D}_{2}$ & 11.22 & 15.64 & 17.75 & 18.19 \\
\hline $\mathbf{V}_{3}$ & 18.14 & 17.26 & 13.02 & $\mathbf{V}_{\mathbf{3}}$ & 11.53 & 16.08 & 18.25 & 18.70 & $\mathbf{D}_{3}$ & 8.46 & 11.79 & 13.38 & 13.71 \\
\hline SEm \pm & 0.15 & & & SEm \pm & 0.27 & & & & SEm \pm & 0.23 & & & \\
\hline CD & 0.42 & & & CD & 0.89 & & & & CD & 0.68 & & & \\
\hline
\end{tabular}


Table.3 Interaction effects of irrigation scheduling, cultivars and varying sowing dates on number of grains per spike of wheat

\begin{tabular}{|c|c|c|c|c|c|c|c|c|c|c|c|c|c|}
\hline \multicolumn{14}{|l|}{ I Year } \\
\hline$V \times D$ & $D_{1}$ & $\mathbf{D}_{2}$ & $\mathbf{D}_{3}$ & I X V & $\mathbf{I}_{1}$ & $\mathbf{I}_{2}$ & $\mathbf{I}_{3}$ & $\mathbf{I}_{\mathbf{4}}$ & I X D & $\mathbf{I}_{1}$ & $\mathbf{I}_{2}$ & $\mathbf{I}_{3}$ & $\mathbf{I}_{4}$ \\
\hline $\mathbf{V}_{1}$ & 32.40 & 30.46 & 23.89 & $V_{1}$ & 21.53 & 28.52 & 32.40 & 33.23 & $\mathbf{D}_{1}$ & 32.10 & 42.52 & 48.31 & 49.55 \\
\hline $\mathbf{V}_{2}$ & 48.85 & 45.93 & 36.02 & $V_{2}$ & 32.46 & 42.99 & 48.85 & 50.10 & $\mathbf{D}_{2}$ & 30.18 & 39.98 & 45.42 & 46.58 \\
\hline$V_{3}$ & 48.11 & 45.23 & 35.47 & $\mathbf{V}_{3}$ & 31.96 & 42.34 & 48.11 & 49.33 & $\mathbf{D}_{3}$ & 23.67 & 31.35 & 35.62 & 36.53 \\
\hline SEm \pm & 0.57 & & & SEm \pm & 0.83 & & & & SEm \pm & 0.66 & & & \\
\hline CD & 1.63 & & & CD & 2.49 & & & & CD & 1.88 & & & \\
\hline \multicolumn{14}{|l|}{ II Year } \\
\hline V x D & $D_{1}$ & $\mathbf{D}_{2}$ & $\mathbf{D}_{3}$ & I X V & $\mathbf{I}_{1}$ & $\mathbf{I}_{2}$ & $\mathbf{I}_{3}$ & $\mathbf{I}_{4}$ & I X D & $\mathbf{I}_{1}$ & $\mathbf{I}_{2}$ & $\mathbf{I}_{3}$ & $\mathbf{I}_{4}$ \\
\hline$V_{1}$ & 34.44 & 32.95 & 25.45 & $V_{1}$ & 22.76 & 30.53 & 34.84 & 35.66 & $D_{1}$ & 32.45 & 43.53 & 49.67 & 50.85 \\
\hline $\mathbf{V}_{2}$ & 49.43 & 47.29 & 36.52 & $\mathbf{V}_{2}$ & 32.66 & 43.81 & 49.99 & 51.18 & $\mathbf{D}_{2}$ & 31.05 & 41.64 & 47.52 & 48.65 \\
\hline $\mathbf{V}_{3}$ & 48.51 & 46.41 & 35.84 & $\mathbf{V}_{3}$ & 32.05 & 42.99 & 49.06 & 50.23 & $\mathbf{D}_{3}$ & 23.98 & 32.16 & 36.70 & 37.57 \\
\hline SEm \pm & 0.59 & & & SEm \pm & 0.86 & & & & SEm \pm & 0.68 & & & \\
\hline CD & 1.67 & & & CD & 2.57 & & & & CD & 1.93 & & & \\
\hline \multicolumn{14}{|l|}{ Pooled } \\
\hline$V \times D$ & $\mathbf{D}_{1}$ & $\mathbf{D}_{2}$ & $\mathbf{D}_{3}$ & I X V & $\mathbf{I}_{1}$ & $\mathbf{I}_{2}$ & $\mathbf{I}_{3}$ & $\mathbf{I}_{4}$ & I X D & $\mathbf{I}_{1}$ & $\mathbf{I}_{2}$ & $\mathbf{I}_{3}$ & $\mathbf{I}_{4}$ \\
\hline$V_{1}$ & 33.42 & 31.71 & 24.67 & $V_{1}$ & 22.14 & 29.52 & 33.62 & 34.45 & $D_{1}$ & 32.28 & 43.02 & 48.99 & 50.20 \\
\hline$V_{2}$ & 49.14 & 46.61 & 36.27 & $\mathbf{V}_{2}$ & 32.56 & 43.40 & 49.42 & 50.64 & $\mathbf{D}_{2}$ & 30.62 & 40.81 & 46.47 & 47.62 \\
\hline$V_{3}$ & 48.31 & 45.82 & 35.65 & $\mathbf{V}_{3}$ & 32.01 & 42.67 & 48.58 & 49.78 & $\mathbf{D}_{3}$ & 23.82 & 31.76 & 36.16 & 37.05 \\
\hline SEm \pm & 0.41 & & & SEm \pm & 0.60 & & & & SEm \pm & 0.60 & & & \\
\hline CD & 1.15 & & & CD & 2.09 & & & & CD & 1.72 & & & \\
\hline
\end{tabular}

\section{Number of grains per spike}

Number of grains spike $^{-1}$ of wheat was significantly influenced by the interaction of cultivar and sowing date. Results revealed (Table: 3.) that the highest number of grains spike $^{-1}$ was obtained from $\mathrm{D}_{1} \mathrm{~V}_{2}(48.85,49.43$ and 49.14) which was statistically similar with $\mathrm{D}_{1} \mathrm{~V}_{3}(48.11,48.51$ and 48.31).

On the other hand the lowest grain spike ${ }^{-1}$ was observed at $\mathrm{D}_{3} \mathrm{~V}_{1}(23.89,25.45$ and 24.67) according to study years and pooled analysis, respectively. Similar results were also reported by (Shahzad et al., 2002; Spink et al., 2000).

Interaction effect of improved wheat cultivar and irrigation showed significant differences on grain spike ${ }^{-1}$ at all sampling dates. Results showed (Table: 3.) that the highest grain spike $^{-1}$ was obtained from $\mathrm{I}_{4} \mathrm{~V}_{2}(50.10,51.18$ and 50.64) which were statistically similar with $\mathrm{I}_{4} \mathrm{~V}_{3}$ (49.33, 50.23 and 49.78), $\mathrm{I}_{3} \mathrm{~V}_{2}$ 
(48.85, 49.99 and 49.42) and $\mathrm{I}_{3} \mathrm{~V}_{3}$ (48.11, 49.06 and 48.58). On the other hand the lowest grain spike ${ }^{-1}$ was observed at $\mathrm{I}_{1} \mathrm{~V}_{1}$ (21.53, 22.76 and 22.14) according to study years and pooled analysis, respectively.

Interaction effect of different levels of irrigation and sowing date showed significant differences on grain spike ${ }^{-1}$ of these three types of modern wheat cultivar. A critical examination of data in table. 3 indicated that the maximum number of grains spike ${ }^{-1}$ was given at $\mathrm{I}_{4} \mathrm{D}_{1}(49.55,50.85$ and 50.20) which were statistically similar with
$\mathrm{I}_{3} \mathrm{D}_{1}$ (48.31, 49.67 and 48.99) and the lowest grain spike ${ }^{-1}$ was observed at $\mathrm{I}_{1} \mathrm{D}_{3}(23.67,23.98$ and 23.82) in 2016-17, 2017-18 and pooled analysis, respectively.

\section{Grain yield}

A critical examination of data (Table: 4.) indicated that the interaction effect of sowing dates and cultivars treatments on grain yield of wheat was found to be significant in both the years of study and pooled analysis.

Table.4 Interaction effects of irrigation scheduling, cultivars and varying sowing dates on grain yield of wheat

\begin{tabular}{|c|c|c|c|c|c|c|c|c|c|c|c|c|c|}
\hline \multicolumn{14}{|l|}{ I Year } \\
\hline$V \times D$ & $D_{1}$ & $\mathbf{D}_{2}$ & $\mathbf{D}_{3}$ & I X V & $\mathbf{I}_{1}$ & $\mathbf{I}_{2}$ & $\mathbf{I}_{3}$ & $\mathbf{I}_{4}$ & I X D & $\mathbf{I}_{1}$ & $\mathbf{I}_{2}$ & $\mathbf{I}_{3}$ & $\mathbf{I}_{4}$ \\
\hline$V_{1}$ & 4374 & 4012 & 2890 & $V_{1}$ & 2908 & 3663 & 4046 & 4418 & $D_{1}$ & 3900 & 5227 & 5625 & 5928 \\
\hline $\mathbf{V}_{2}$ & 5777 & 5074 & 3953 & $\mathbf{V}_{2}$ & 3612 & 5028 & 5541 & 5556 & $\mathbf{D}_{2}$ & 3684 & 4822 & 5106 & 5374 \\
\hline$V_{3}$ & 5359 & 5154 & 3969 & $V_{3}$ & 3732 & 5017 & 5256 & 5303 & $\mathbf{D}_{3}$ & 2668 & 3660 & 4112 & 3976 \\
\hline SEm \pm & 70 & & & SEm \pm & 101 & & & & SEm \pm & 81 & & & \\
\hline CD & 199 & & & CD & 304 & & & & CD & 229 & & & \\
\hline \multicolumn{14}{|l|}{ II Year } \\
\hline V x D & $\mathrm{D}_{1}$ & $\mathbf{D}_{2}$ & $\mathbf{D}_{3}$ & I X V & $\mathbf{I}_{1}$ & $\mathbf{I}_{2}$ & $\mathbf{I}_{3}$ & $\mathbf{I}_{4}$ & I X D & $\mathbf{I}_{1}$ & $\mathbf{I}_{2}$ & $\mathbf{I}_{3}$ & $\mathbf{I}_{4}$ \\
\hline$V_{1}$ & 4429 & 4065 & 2956 & $V_{1}$ & 2941 & 3718 & 4109 & 4498 & $D_{1}$ & 3941 & 5289 & 5689 & 6008 \\
\hline$V_{2}$ & 5848 & 5153 & 4036 & $V_{2}$ & 3653 & 5090 & 5653 & 5654 & $\mathbf{D}_{2}$ & 3739 & 4874 & 5181 & 5457 \\
\hline$V_{3}$ & 5419 & 5221 & 4042 & $V_{3}$ & 3803 & 5082 & 5310 & 5381 & $\mathbf{D}_{3}$ & 2717 & 3726 & 4201 & 4068 \\
\hline SEm \pm & 72 & & & SEm \pm & 120 & & & & SEm \pm & 83 & & & \\
\hline CD & 203 & & & CD & 360 & & & & CD & 235 & & & \\
\hline \multicolumn{14}{|l|}{ Pooled } \\
\hline V x D & $D_{1}$ & $\mathbf{D}_{2}$ & $\mathbf{D}_{3}$ & I X V & $\mathbf{I}_{1}$ & $\mathbf{I}_{2}$ & $\mathbf{I}_{3}$ & $\mathbf{I}_{4}$ & I X D & $\mathbf{I}_{1}$ & & $\mathbf{I}_{3}$ & $\mathbf{I}_{4}$ \\
\hline$V_{1}$ & 4401 & 4039 & 2923 & $V_{1}$ & 2924 & 3690 & 4077 & 4458 & $D_{1}$ & 3921 & 5258 & 5657 & 5968 \\
\hline$V_{2}$ & 5813 & 5113 & 3994 & $\mathbf{V}_{2}$ & 3633 & 5059 & 5597 & 5605 & $\mathbf{D}_{2}$ & 3712 & 4848 & 5144 & 5416 \\
\hline$V_{3}$ & 5389 & 5188 & 4006 & $V_{3}$ & 3768 & 5049 & 5283 & 5342 & $\mathbf{D}_{3}$ & 2692 & 3693 & 4157 & 4022 \\
\hline SEm \pm & 50 & & & SEm \pm & 79 & & & & SEm \pm & 79 & & & \\
\hline CD & 140 & & & CD & 227 & & & & CD & 227 & & & \\
\hline
\end{tabular}


The treatment combination $\mathrm{D}_{1} \mathrm{~V}_{2}$ recorded the significantly higher grain yield $(5777,5848$ and $5813 \mathrm{kgha}^{-1}$ ) over rest of the treatment combinations and the minimum grain yield was recorded under $\mathrm{D}_{3} \mathrm{~V}_{1}(2890,2956$ and $2923 \mathrm{kgha}^{-1}$ ) in 2016-17, 2017-18 and pooled analysis, respectively.

Interaction effect of improved wheat cultivar and irrigation showed significant differences on grain yield. Results showed (Table: 4.) that the highest grain yield was obtained from $\mathrm{I}_{4} \mathrm{~V}_{2}$ (5556 and $5654 \mathrm{kgha}^{-1}$ ) which were statistically similar with $\mathrm{I}_{4} \mathrm{~V}_{3}$ (5303 and 5381 $\left.\mathrm{kgha}^{-1}\right), \mathrm{I}_{3} \mathrm{~V}_{2}$ (5541 and $5653 \mathrm{kgha}^{-1}$ ) and $\mathrm{I}_{3} \mathrm{~V}_{3}$ (5256 and $5310 \mathrm{kgha}^{-1}$ ) in 2016-17 and 201718. Further data revealed that in pooled analysis highest grain yield was obtained from $\mathrm{I}_{4} \mathrm{~V}_{2}(5605 \mathrm{~kg} / \mathrm{ha})$ except $\mathrm{I}_{3} \mathrm{~V}_{2} \quad(5597$ $\mathrm{kgha}^{-1}$ ).

On the other hand the lowest grain yield was observed at $\mathrm{I}_{1} \mathrm{~V}_{1}$ (2908, 2941 and $2924 \mathrm{kgha}^{-}$ $\left.{ }^{1}\right)$ according to study years and pooled analysis, respectively.

Interaction effect of different levels of irrigation and sowing date showed significant differences on grain yield of these three types of modern wheat Cultivar. Results (Table: 4.) showed that the maximum grain yield was recorded at $\mathrm{I}_{4} \mathrm{D}_{1}(5928,6008$ and $5968 \mathrm{~kg} / \mathrm{ha})$ and the lowest grain yield was observed at $\mathrm{I}_{1} \mathrm{D}_{3}(2668,2717$ and $2692 \mathrm{~kg} / \mathrm{ha})$ in 2016-17, 2017-18 and pooled analysis, respectively. These results are in accordance with those of (Spink et al., 2000; Aslam et al., 2003; Joshi et al., 2016).

\section{References}

Anonymous, 2015a. United States Department of Agriculture, World Agricultural Production, Foreign Agriculture Service, Circular Series, WAP.
Aslam, M., Hussain, M., Akhtar, M., Cheema, M.S. and Ali, L. 2003. Response of wheat varieties to sowing dates. Pakistan Journal of Agronomy 2: 190194.

Dixit, A.K., Kumar, S., Rai, A.K. and Kumar, T.K. 2014. Tillage and irrigation management in chickpea-fodder sorghum cropping system under semiarid conditions of India. Indian Journal of Agronomy 59: 575-580.

DWR Annual Report. Annual report of field crops. DWR report, 2015, 18.

Hussain, I., Ahmad, H.B., Rauf, S., Aslam, M. and Aulakh, A.M., 2015. Effect of sowing time on quality attributes of wheat grain. International Journal of Bioscience 6: 1-8.

ICAR-IIWBR, 2018. Director's Report of AICRP on Wheat and Barley Improvement Project 2017-18. Ed: G. P. Singh, ICAR-Indian Institute of Wheat and Barley Research, Karnal, India, 94.

Joshi, M.A., Faridullah, S. and Kumar, A. 2016. Effect of heat stress on crop phenology, yield and seed quality attributes of wheat. Journal of Agrometeorology 18: 206-215.

Matuz, J. and Aziz, J.S. 1990. The effect of sowing season on Iraqi and Hungarian wheat varieties. Cereal Research Communication 18: 41-43.

Mehta and Mattur, 1979. Effect of different dates of sowing \& nutrients on growth $\&$ yield of wheat cultivars. Agric. Sci. Digest., 21(2): 239-248.

Mesbah, E.A.E. 2009. Effect of irrigation regimes and foliar spray of potassium on yield, yield attributes and water use efficiency of wheat in sandy soils. World Journal of Agricultural Science 5: 662-669.

Saini, Solanki, NS., 1988. Effect of environmental factors on growth \& yield of wheat. Journal of Plant Development Sci., 8(12). 
Shah, W.A., Bakht, J., Ullah, T., Khan, A.W., Zubair, M. and Khakwani, A. 2006. Effect of sowing dates on yield and yield components of different wheat varieties. Indian Journal of Agronomy 5: 106-110.

Shahzad, K., Bakht, J., Shah, W.A., Shafi, M. and Jabeen, N. 2002. Yield and yield components of various wheat cultivars as affected by different sowing dates. Asian Journal of Plant Science 1: 522525.

Singh, T., 1997 Effect of different dates of sowing on different wheat varieties. $J$. Agric Res, 48(3).

Spink, J.H., Semere, T., Sparkes, D.L., Wahley, J.M., Foulkes, M.J., Calre,
R.W. and Scatt, R.K. 2000. Effect of sowing dates and planting density of winter wheat. Annals of Applied Biology 137: 179-188.

Suhail, S., Shah, M. and Akmal, M. 2002 Effect of different sowing dates on yield and yield component of wheat varieties. Sarhad Journal of Agriculture 18: 143149.

Wajid, A., Hussain, A., Ahmad A, Goheer, A.R., Ibrahim., M, Mussaddique, M. (2004). Effect of Sowing Date \& Plant Population on Biomass, Grain Yield \& Yield Components of Wheat. International Journal of Agriculture \& Biology.1560-1565.

\section{How to cite this article:}

Arjun Lal Prajapat, Rani Saxena, R. C. Sanwal and Manoj Kumhar. 2020. Interaction Effect of Different Sowing Dates and Irrigation Schedule on Yield Attributes of Wheat Cultivars under Rajasthan Conditions. Int.J.Curr.Microbiol.App.Sci. 9(02): 976-984.

doi: https://doi.org/10.20546/ijcmas.2020.902.114 